\title{
Stimulasi Intervensi Deteksi Dini Tumbuh Kembang (SIDTK) di TK Nurul Hikmah Nagari Kasang Batang Anai Padang Pariaman
}

\author{
Anggawati Imanniyah*1, Dewi Susilawati ${ }^{2}$, Rini Rahma Yanti ${ }^{3}$ \\ 1,2,3 STIKes Mercubaktijaya Padang, J1. Jamal Jamil Pondok Kopi Siteba Padang \\ ${ }^{1 *}$ Prodi D III Terapi Wicara, ${ }^{2}$ Prodi S-1 Kebidanan, ${ }^{3}$ Prodi S-1 Keperawatan \\ ${ }^{* 1}$ e-mail: anggaimanniyah@gmail.com
}

Informasi Artikel

Diterima Redaksi: 23 April 2020

Revisi Akhir: 31 Mei 2020

Diterbitkan Online: 1 Juni 2020

Kata Kunci:

Perkembangan, Pertumbuhan, SIDTK

\section{PENDAHULUAN}

Mengingat masa 5 tahun pertama merupakan masa yang "relatif pendek" dan tidak akan terulang kembali dalam kehidupan seorang anak, maka para orang tua,pengasuh dan pendidik harus memanfaatkan periode yang singkat ini untuk membentuk anak menjadi bagian dari generasi penerus yang tangguh dan berkualitas (Bracken, 2009:Jeharsae et al.,2015).

Salah satu upaya dalam bidang kesehatan adalah melakukan Stimulasi Intervensi Deteksi Dini Tumbuh Kembang anak yang disingkat dengan SIDTK oleh semua pihak, karena melalui kegiatan SIDTK kondisi terparah dari penyimpangan pertumbuhan seperti gizi buruk dapat dicegah, selain itu penyimpangan perkembangan mental emosional dapat dideteksi lebih awal agar

\section{Abstrak}

Kegiatan pelayanan masyarakat ini bertujuan untuk mendorong pertumbuhan dan perkembangan anak-anak secara komprehensif dan berkualitas melalui kegiatan stimulasi, deteksi, dan intervensi awal untuk pertumbuhan dan penyimpangan perkembangan dalam 5 tahun pertama kehidupan. SIDTK dilakukan di wilayah Puskesmas Pasar Usang, khususnya di TK Nurul Hikmah Kanagarian Kasang. Kegiatan pengabdian ini dilakukan dengan mendeteksi pertumbuhan dan perkembangan anak-anak di TK Nurul Hikmah dengan melompat langsung pada anakanak untuk mendapatkan hasil pemeriksaan langsung seperti berat badan, tinggi badan, lingkar kepala, dan masalah emosi mental serta keterlambatan dalam komunikasi, yaitu bahasa dan ucapan. Pencapaian tujuan ini dilakukan melalui pelatihan dengan ceramah, tanya jawab dan memberikan metode intervensi. Adapun saran yang dapat disampaikan dari hasil pengabdian masyarakat, bagi guru TK diharapkan selalu mencari kegiatan SDITK untuk siswanya. Praktisi kesehatan diharapkan dapat membantu guru TK dalam melakukan SIDTK secara teratur. Untuk LP2M melalui STIKes Mercubaktijaya Padang harus selalu menarik program serupa untuk terus diimplementasikan dan dikembangkan.

tidak terjadi gangguan dan penyimpangan yang menetap. Kegiatan SIDTK tidak hanya dilakukan pada anak yang dicurigai mempunyai masalah saja tetapi harus dilakukan pada bayi, balita dan anak pra sekolah secara rutin.

SIDTK adalah pembinaan tumbuh kembang anak secara komprehensif dan berkualitas melalui kegiatan stimulasi, deteksi dan intervensi dini terhadap penyimpangan tumbuh kembang pada masa 5 tahun pertama kehidupan. Kegiatan ini diselenggarakan dalam bentuk kemitraan antara keluarga, masyarakat dengan tenaga professional (kesehatan, pendidikan dan sosial).

Puskesmas Pasar Usang merupakan salah satu Puskesmas yang berada diKecamatan Batang Anai, Kabupaten Padang Pariaman Provinsi Sumatera Barat. Jarak Puskesmas 
tersebut tidak jauh dari STIKes MERCUBAKTIJAYA Padang, tempat tim pengabdi melaksanakan pendidikan, diperkirakan jarak lokasi dari kampus berkisar $20 \mathrm{KM}$. Puskesmas Pasar Usang merupakan Puskesmas Rawat Inap dengan Akreditasi Madya . Terletak pada Jalan Raya Padang Bukittinggi. Tenaga perawat berjumlah 34 orang, Bidan desa 19 orang, Tenaga swakelola 3 orang, Pustu 4, Polindes 14 dan memiliki Nagari 3 Nagari, 23 korong. Jumlah KK 8.235 KK dengan jumlah Penduduk 32.336 jiwa.

Salah satu wilayah kerja puskesmas Pasar Usang ini adalah nagari Kasang yang akan menjadi sasaran dalam pengabdian masyarakat ini, tepatnya di TK Nurul Hikmah Nagari kasang di Kecamatan Batang Anai. Nagari Kasang merupakan salah satu nagari yang terdapat dalam kecamatan Batang Anai, Kabupaten Padang Pariaman, Provinsi Sumatera Barat.

Sebelum munculnya industri di Nagari Kasang, pada umumnya mata pencaharian penduduk lebih didominasi oleh sektor pertanian. Setelah keberadaan industri tersebut, banyak dari angkatan kerjanya beralih profesi di luar sektor pertanian. Sektor usaha lain adalah munculnya unit usaha warung dan toko menjual keperluan harian dan pedagang minuman dan makanan.

Wilayah kerja Puskesmas Pasar Usang cakupan pelayanan kesehatan pada anak masih rendah, khususnya deteksi dini tumbuh kembang pada balita masih $71,7 \%$. Dari hasil survei lapangan dan wawancara kepada pimpinan Puskesmas setempat didapatkan permasalahan yang dialami yaitu pelaksanaan skrining SIDTK di puskesmas hanya melakukan skrining pada balita yang dicurigai mengalami keterlambatan tumbuh kembang saja.

Selain itu, permasalahan yang ditemukan lainnya seperti stimulasi, deteksi dan intervensi dini tumbuh kembang yang dilakukan di Posyandu pun tidak lengkap, hanya penimbangan berat badan dan tinggi badan saja. Dan juga kader posyandu belum mampu melakukan deteksi dini dan intervensi dini penyimpangan tumbuh kembang balita secara komprehensif. Padahal pendeteksian dini tumbuh kembang anak yang dilakukan oleh kader posyandu sangatlah penting, sehingga apabila terdapat anak yang mengalami penyimpangan dalam hal tumbuh kembang, kader dapat langsung menyampaikan kepada orang tua atau pihak puskesmas untuk dirujuk ke pusat pelayanan kesehatan terdekat.

\section{METODE}

Dalam rangka mengatasi permasalahan yang dihadapi oleh mitra dimana belum pernah dilakukannya deteksi dini tumbuh kembang dan keterlambatan bicara pada anak pra sekolah di TK Nurul Hikmah, Nagari Kasang, Kabupaten Padang Pariaman. Adapun metode pelaksanaan kegiatan pengabdian masyarakat yang dilakukan ialah sebagai berikut :

1. Pertemuan dan Berkoordinasi dengan Pihak Mitra. Kegiatan pengabdian masyarakat ini diselenggarakan dengan melibatkan berbagai pihak yang berperan dalam pemberian izin, sosialisasi kegiatan kepada sasaran, dan pendaftaran anggota.

2. Mengidentifikasi masalah yang terjadi pada mitra.

3. Memberikan informasi dan deteksi dini tumbuh kembang \& keterlambatan bicara dengan narasumber dari Dosen STIKes Mercubaktijaya Padang sebanyak tiga orang yang berperan dalam Stimuklasi intervensi dini tumbuh kembang di TK Nurul Himah

4. Guru TK Nurul Hikmah di Kecamatan Busungbiu sebagai peserta pelatihan

5. Panitia pelaksana kegiatan yang berperan dalam perencanaan, pelaksanaan, dan refleksi kegiatan.

Metode pelaksanaan pengabdian masyarakat yang digunakan untuk mendukung keberhasilan program antara lain sebagai berikut:

1. Ceramah dan Tanya Jawab. Metode ini dipilih untuk membangkitkan motivasi guru dalam mengikuti kegiatan penyuluhan informasi/edukasi tentang deteksi dini tumbuh kembang.

2. Pemberian Intervensi dengn membuat instrumen deteksi dini tumbuh kembang.

3. Melaksanakan kegiatan deteksi dini tumbuh kembang yg terdiri dari:

a. Penimbangan BB \& pengukuran TB

b. Deteksi gangguan daya lihat 
c. Deteksi gangguan daya dengan

d. Deteksi gangguan bicara

e. Deteksi masalah mental dan emosional

Untuk mengetahui keberhasilan kegiatan ini, dilakukan dengan melihat keterlibatan dan antusias peserta. Keterlibatan peserta dapat dilihat dari absen peserta kegiatan dan antusiame peserta dilihat dari hasil peserta selama kegiatan berlangsung. Digunakan juga metode angket/kuesioner untuk mengumpulkan data mengenai respons guru terhadap pelaksanaan pelatihan.

\section{HASIL DAN PEMBAHASAN}

Pelaksanaan kegiatan pengabdian masyarakat ini membutuhkan waktu secara menyeluruh selama 1 (satu) bulan. Kegiatan pengabdian masyarakat mengenai stimulasi intervensi dini tumbuh kembang di TK Nurul Hikmah Nagari Kasang Batang Anai Padang Pariaman ini. Dalam pelaksana kegiatan tersebut telah di peroleh hasil pertumbuhan dan perkembangan sesuai instrument yang sudah disediakan, berikut adalah hasil pemeriksaan pada anak usia dini di TK Nurul Hikmah :

Tabel 1. Hasil Pemeriksaan Anak Usia Dini di TK Nurul Hikmah

\begin{tabular}{ccccccccc}
\hline \multirow{2}{*}{ No } & Nama & Usia & \multicolumn{3}{c}{ Pertumbuhan } & \multicolumn{2}{c}{ Perkembangan } & Hasil \\
& (Inisial) & (tahun) & BB & TB & LK & TDL & TDD & Pemeriksaan \\
\hline 1 & IH & 4,8 & 15 & 108 & 47 & Normal & Normal & Normal \\
& & & $\mathrm{kg}$ & $\mathrm{cm}$ & $\mathrm{cm}$ & & & \\
2 & PD & 5 & 16 & 105 & 48 & Normal & Normal & Normal \\
& & & $\mathrm{kg}$ & $\mathrm{cm}$ & $\mathrm{cm}$ & & & \\
3 & DV & 4 & 20 & 114 & 53 & Normal & Normal & Normal \\
& & & $\mathrm{kg}$ & $\mathrm{cm}$ & $\mathrm{cm}$ & & & \\
4 & $\mathrm{NL}$ & 4,2 & 18 & 112 & 52 & Normal & Normal & Normal \\
& & & $\mathrm{kg}$ & $\mathrm{cm}$ & $\mathrm{cm}$ & & & \\
5 & NS & 3,5 & 13 & 100 & 50 & Normal & Normal & Normal \\
& & & $\mathrm{kg}$ & $\mathrm{cm}$ & $\mathrm{cm}$ & & & \\
6 & ZI & 4,7 & 24 & 118 & 53 & Normal & Normal & Normal \\
& & & $\mathrm{kg}$ & $\mathrm{cm}$ & $\mathrm{cm}$ & & & \\
\hline
\end{tabular}

Dari hasil pemeriksaan tersebut rata-rata anak usia dini di TK Nurul Hikmah Nagari Kasang dengan hasil normal. Adapun hasil diskusi pada pelatihan ini menunjukkan peningkatan pengetahuan dan respon positif peserta. Dari banyaknya pertanyaan peserta menunjukan bahwa pengetahuan peserta yang semua belum memadai, namun setelah mengikuti pelatihan ternyata ada peningkatan kefahaman tentang konsep SDITK. Para guru terlihat antusiasi dalam menyimak dan berdiskusi ketika narasumber berbagi pengalaman mengenai stimulasi deteksi intervensi dini tumbuh kembang anak, antusiame ini disebabkan oleh berbagai alasan, seperti keinginan guru untuk meningkatkan profesionalisme, terutama dalam melaksanakan pencegahan kelainan tumbuh kembang yang terjadi pada anak.

Hal yang perlu mendapatkan perhatian adalah kendala yang dialami oleh guru ketika mengikuti penyuluhan stimulasi deteksi intervensi dini tumbuh kembang tidak semua guru mengikuti atau hadir dikarenakan sesuatu hal urusan sehingga belum sepenuhnya memahami mengenai pentingnya SDITK pada anak usia dini. Guru-guru terlihat kesulitan mengidentifikasi masalah yang dimiliki. Namun setelah pendampingan yang dilakukan dengan melibatkan narasumber dan panitia pelaksana, kesulitan ini dapat ditasi. Guru-guru terlihat begiru bersemangat untuk saling menyampaikan masalah yang dimiliki dan rekaan solusi yang ditawarkan untuk mengatasi masalah yang dihadapi.

\section{KESIMPULAN}

Ada peningkatan pengetahuan pada guru tentang stimulasi deteksi intervensi dini tumbuh kembang anak, serta pada saat pelaksanaan SDITK terlihat pertumbuhan dan perkembangan anak di TK Nurul Hikmah Nagarai kasang hasilnya normal. 
Wawasan peserta guru TK bertambah terbukti pada diskusi banyak sekali keinginan tahuan mereka tentang cara pencegahan dan penanggulangan kelainan tumbuh kembang anak. Baik sebelum maupun sesudah anak lahir.

\section{SARAN}

Kegiatan pengabdian ini mampu meningkatkan pengetahuan dan pemahaman guru dalam stimulasi deteksi intervensi dini tumbuh kembang anak usia dini serta memiliki alat instrument yang diberikan pada saat penyuluhan yang bertujuan sebagai pedoman jika ada anak yang mengalami gangguan dalam pertumbuhan dan perkembangannya.

\section{UCAPAN TERIMA KASIH}

Penulisan ini dapat terwujud dan terselesaikan dengan baik karena adanya bantuan dari berbagai macam pihak, terima kasih kepada:

1.Ketua Yayasan Mercubaktijaya beserta staf dan jajaranya.

2.Ketua Stikes Mercubaktijaya Padang beserta seluruh civitas akademika.

3.Pihak terkait yang telah membantu dalam kelancaran pelaksanaan penelitian.

Dalam penyusunan ini, penulis menyadari masih banyak kekurangan karena keterbatasan pengetahuan. Oleh karena itu, segala kritik dan saran yang bersifat membangun sangat penulis harapkan. Semoga penelitian ini dapat memberikan manfaat dan dapat menjadi salah satu bahan informasi pengetahuan bagi para pembaca sekalian.

\section{REFERENSI}

[1] Bracken, B.A. (2009). Growing healthy self-concepts. In R. Gilman, S. Huebner, \& M. Furlong (Eds.). Promoting wellness in children and youth: A handbook of positive psychology in the schools (pp.89106). Boston: Blackwell.

[2] Departemen Kesehatan RI. (2010). Pedoman pelaksanaan stimulasi, deteksi, dan intervensi dini tumbuh kembang. Jakarta: Depkes RI.
[3] Departemen Kesehatan RI. (2012). Pedoman pelaksanaan stimulasi, deteksi, dan intervensi dini tumbuh kembang anak di tingkat pelayanan kesehatan dasar. Jakarta: Depkes RI. 